\title{
Water Balance in the Sivash Bay as a Result of Variability of the Natural-Climatic and Anthropogenic Factors
}

\author{
E. E. Sovga*, E. S. Eryemina, T. V. Khmara \\ Marine Hydrophysical Institute, Russian Academy of Sciences, Sevastopol, Russian Federation \\ *e-mail: esovga@mhi-ras.ru
}

\begin{abstract}
Dynamics of the Sivash Bay (the Sea of Azov) water balance under the conditions of varying natural and climatic (precipitation, water exchange with the Sea of Azov, river flow and evaporation), and anthropogenic factors (overlap of the North-Crimean Canal in 2014 and change of nature management) is studied. The basic water balance components in the Sivash Bay are assessed for three periods: the first one (1939-1971) - before the North-Crimean Canal was put into operation (conditionally natural mode of the Sivash Bay waters) - is studied using historical data; the second one (1972-2013) - during active exploitation of the canal under various functioning regimes of the irrigation systems, and the third period (2014-2016) - after the Canal was overlapped - are studied using the in situ data obtained by Marine Hydrophysical Institute and allowing for the modified natural and climatic factors. Intensity of water exchange between the Sivash Bay and the Sea of Azov after the canal was overlapped and the Sivash or the Azov currents became predominant is assessed using the calculation of the water level variations in the indicated areas and taking into account the wind conditions in summer, 2014. It is shown that the eastern winds promote intensification of the Azov water inflow to the Sivash Bay, hence, increasing salinity of its waters.

Thus, overlap of the North-Crimean Canal in 2014 makes for a complete reconstruction of the hydrological water regime in the bay and its gradual transition to the conditionally natural state.
\end{abstract}

Keywords: Sivash Bay, river runoff, atmospheric precipitation, water balance, salinity, NorthCrimean Canal, the Henichesk Strait, water exchange with the Sea of Azov, water level.

Acknowledgments. The work was carried out within the framework of the state order on the topic No. 0827-2014-0011 "Studies of the regularities of the marine environment condition changes on the basis of operational observations and data from the system of now cast, prognosis and reanalysis of the state of marine areas" ("Operational Oceanography" code), and with partial support of RFBR, grant No. 16-05-00621.

For citation: Sovga, E.E., Eryemina, E.S. and Khmara, T.V., 2018. Water Balance in the Sivash Bay as a Result of Variability of the Natural-climatic and Anthropogenic Factors. Physical Oceanography, [e-journal] 25(1), pp. 67-76. doi:10.22449/1573-160X-2018-1-67-76

DOI: 10.22449/1573-160X-2018-1-67-76

(C) 2018, E. E. Sovga, E. S. Eryemina, T. V. Khmara

(C) 2018, Physical Oceanography

\section{Introduction}

The Sivash Bay, the gulf of the Sea of Azov, is the most anthropogenically and technogenically loaded water area of the Crimean coastal zone where intensive specific hydrodynamic and hydrochemical processes take place. This activity is due to variability of both natural-climatic (shore orography, bottom terrain features, shallow depths, interaction with the Sea of Azov waters, atmospheric precipitation, river runoff) and anthropogenic (functioning and overlapping of the North-Crimean Canal (NCC), change of environmental management system) factors.

The bay natural hydrologic regime was mainly violated by the NCC building during 1961-1971. It made certain ecologic problems. 
According to previous studies [4, 5], the Eastern Sivash, which is the largest by the area (1650 $\mathrm{km}^{2}$ and more than $60 \%$ of the total area of the Sivash Bay) and the deepest (down to $1 \mathrm{~m}$ depths occupy $41 \%$ of its area) part of the bay, was most badly affected by fresh water discharge. The volume of fresh water entering the bay was increased and it had led to a decrease in salinity as well as an increase in the level of the Sivash Bay and, as a result, to a decrease in the volume of the Sea of Azov inflowing waters.

A limited number of works is devoted to the analysis of certain components of the Sivash Bay water balance. The works of A. Ponizovsky [1, 2], the ones carried out with support of Wetlands International - AEME international organization in 2000, 2005 and 2007 [3-5] and the studies of Sevastopol Branch of State Oceanographic Institute [6-8] should be noticed. The present study [9] is also devoted to the Sivash Bay water area during the functioning of the NCC. Analysis of the abovementioned works reveals the fact that they have the following drawbacks:

Firstly, not all water balance components were considered in the listed works. In [7] such important component as evaporation was not taken into account and those water balance items which, according to the authors, are largely determined by natural climatic factors (atmospheric precipitation, river runoff, water exchange with the Sea of Azov) were analyzed.

Secondly, the bay volume was not calculated in the abovementioned studies. It was not allowed to estimate the volume variability depending on the climatic and anthropogenic changes in different periods of the NCC functioning. Moreover, in [6-8] when calculating water balance components a data for a very long time interval from 1939 to 2010, which includes periods of relatively natural state of the bay (1939-1971) and anthropogenically changed one (associated with the bringing of the NCC into operation (1972-2010)), were analyzed and averaged. At the same time, none of the works considered a period after the NCC overlapping in 2014. This paper attempts to consider the mentioned drawbacks.

A purpose of the present work is to assess the main water balance components of the Sivash Bay for different periods: before the NCC was brought into operation (a period of relatively natural regime of the Sivash Bay (1939-1972)), a period of intensive canal operation under different operating modes of existing irrigation systems (1972-2013) and after overlapping of the canal (2014-2016).

\section{Materials and research methods}

The Sivash Bay input and output items were analyzed on the basis of historical and literature data obtained before the NCC was brought into operation [1, 2], during its active use [3-5, 9] and also on the basis of the in situ data obtained after the canal overlapping (2014-2016) [10, 11], as well as the calculations using available meteorological information [12].

The Sivash Bay water balance includes the following input and output items:

I. Input items:

1) the Sea of Azov water inflow through the Henichesk Strait (the Tonkiy and Promoina Straits),

2) atmospheric precipitation, 
3) drainage and discharge waters of the NCC and Kahovskaya irrigation system,

4) surface and underground runoff of the Sivash Bay basin,

5) the Sea of Azov water filtering through the Arabat Spit (does not taken into account in the present work).

II. Output items:

1) evaporation from the Sivash Bay water area,

2) the Sivash Bay water inflow to the Sea of Azov.

To calculate the water balance the equation given in [7, p. 440] was applied as following

$$
\begin{gathered}
F+Q_{\mathrm{AS}}-Q_{\mathrm{SS}}=\Delta B, \\
F=V_{\mathrm{r}}+V_{\mathrm{NCC}}+V_{\mathrm{pr}}-V_{\mathrm{ev}},
\end{gathered}
$$

where $\Delta B$ is the bay volume variation, $\mathrm{km}^{3} ; F$ is a fresh water component of the balance; $Q_{\mathrm{As}}-Q_{\mathrm{ss}}$ are the water exchange through the Henichesk Strait $\left(Q_{\mathrm{AS}}\right.$ is a water inflow from the Sea of Azov, $Q_{\text {ss }}$ is the Sivash Bay water runoff into the Sea of Azov), $\mathrm{km}^{3} ; V_{\mathrm{r}}, V_{\mathrm{NCC}}, V_{\mathrm{pr}}, V_{\mathrm{ev}}$ are the runoff of the rivers, drainage waters from the NCC and Kahovskaya irrigation system, precipitation and evaporation from the bay surface, respectively, $\mathrm{km}^{3}$.

River runoff was assessed by the observations carried out at the main rivers flowing into the Sivash Bay (the Salhir, the Sukhoi Indol and the Churuk-Su) from 1936 to 2010. Total runoff of small rivers into the Sivash Bay and drainage water discharge from the NCC and Kahovskaya irrigation system was estimated according to [3,5]. An amount of precipitation fallen on the Sivash Bay surface was calculated using the precipitation dataset of GPCP (Global Precipitation Climatology Center) over 1910-2010 [13] and for 2014-2016 precipitation was calculated according to the data of the Henichesk marine hydrometeorological station $(\mathrm{MH})[12]$.

An intensity of the Sivash Bay water exchange with the Sea of Azov over 1972-2010 was assessed by the data from [14] and after the NCC overlapping in 2014 it was assessed indirectly (due to the absence of data from MH Henichesk) by the analysis of the wind situation and calculated data by the Sivash Bay level and the Sea of Azov level variation.

Evaporation was calculated using the Dalton formula, methodology for the calculation was described in [15], mean wind velocity and relative air humidity were obtained from the Henichesk MH database [12]. The satellite data obtained from NASA satellite data were used to estimate monthly average sea surface temperature [16].

\section{Results and discussion}

Some components of the Sivash Bay water balance are represented most completely in [7] where the data and calculations for two periods of the Sivash Bay observations are united: its conditionally natural state (1936-1974) and the state under conditions of the NCC and Kavoskaya irrigation system operation (19742010). 
According to the data from [7], input components of the Sivash Bay water balance indicate that such climate factors as an increase of precipitation and a decrease of salt input with the Sea of Azov water, played an important role in the Sivash Bay freshening equally with anthropogenic impact (discharge of drainage water of the NCC and Kahovskaya irrigation system). Thus, the input item of the Sivash Bay water balance is related to the increase of precipitation and river runoff which are due to regional manifestation of global climate changes.

Table 1

\section{Water balance of the Sivash Bay and variation of its volume $(\Delta B)$ over the investigated periods}

\begin{tabular}{|c|c|c|c|c|c|c|c|}
\hline \multirow[b]{2}{*}{ Values } & \multicolumn{4}{|c|}{ Water balance input items, $\mathrm{km}^{3}$} & \multicolumn{2}{|c|}{$\begin{array}{c}\text { Water balance output } \\
\text { items, } \mathrm{km}^{3}\end{array}$} & \multirow[b]{2}{*}{$\begin{array}{l}\Delta B^{1}, \\
\mathrm{~km}^{3}\end{array}$} \\
\hline & $\begin{array}{c}\text { The Sea } \\
\text { of Azov } \\
\text { inflow, } \\
Q_{\text {as }}\end{array}$ & $\begin{array}{c}\text { River } \\
\text { runoff, } \\
V_{\mathrm{r}}\end{array}$ & $\begin{array}{c}\text { Atmo- } \\
\text { spheric } \\
\text { precipita- } \\
\text { tion, } V_{\mathrm{pr}}\end{array}$ & $\begin{array}{l}\text { Draina } \\
\text { ge, } V_{\mathrm{dr}}\end{array}$ & $\begin{array}{c}\text { The Sivash } \\
\text { rapa runoff, } \\
Q_{\text {ss }}\end{array}$ & $\begin{array}{c}\text { Evapo- } \\
\text { ration, } \\
V_{\mathrm{ev}}\end{array}$ & \\
\hline
\end{tabular}

The period before the NCC construction (1939-1971) (according to [1, 2])

\begin{tabular}{l|c|c|c|c|c|c|c}
\hline minimum & 0.650 & 0.250 & 0.89 & - & 0.060 & 1.10 & 0.63 \\
\hline maximum & 1.960 & 0.250 & 0.89 & - & 0.430 & 1.86 & 0.81 \\
\hline mean & 1.000 & 0.250 & 0.89 & - & 0.370 & 1.24 & 0.53 \\
\hline
\end{tabular}

The period of NCC functioning (1971-2007) (according to [3-5])

\begin{tabular}{l|l|l|l|l|l|l|l}
\hline minimum & 0.883 & 0.119 & 0.89 & 0.681 & 0.430 & 1.10 & 1.04 \\
\hline maximum & 1.887 & 0.310 & 0.89 & 0.773 & 0.807 & 1.24 & 1.73 \\
\hline mean & 1.220 & 0.240 & 0.89 & 0.630 & 0.607 & 1.20 & 1.17 \\
\hline
\end{tabular}

Two periods are combined: conditionally-natural one and the period of the NCC functioning (according to [7])

\begin{tabular}{l|c|c|c|c|c|c|c|c}
\hline mean & 1.220 & 0.083 & 0.96 & 0.630 & 0.410 & 1.20 & 1.28 \\
\hline \multicolumn{7}{c}{$1936-1970^{2}$} \\
\hline mean & 1.510 & 0.063 & 0.82 & - & 0.324 & 1.10 & 0.97 \\
\hline \multicolumn{7}{c}{$1974-2010^{2}$} \\
\hline mean & 0.960 & 0.111 & 1.08 & 0.772 & 0.463 & 1.24 & 1.25 \\
\hline
\end{tabular}

The period after the NCC overlapping (2014-2016)

\begin{tabular}{l|l|l|l|l|l|l|l}
\hline maximum & 1.560 & 0.240 & 1.08 & - & 0.460 & 1.86 & 0.56 \\
\hline mean & 1.220 & 0.119 & 0.85 & - & 0.320 & 1.24 & 0.63 \\
\hline
\end{tabular}

${ }^{1}$ calculated in the present work

${ }^{2}$ calculated in the present work according to [7]

The calculated input and output items of the Sivash Bay water balance and volume, carried out in this work, are given in Table 1. It should be noted that as the 
water balance vary within rather wide limits depending on change of natural-climatic and anthropogenic factors, the minimum, maximum and mean water balance components were calculated over all periods. Therefore the obtained bay volume provides only its relative variation depending on conditions in certain period.

According to Table 1, during the NCC functioning both anthropogenic (drainage and discharge waters of the NCC and Kahovskaya irrigation system) and natural climatic (an increase of precipitation volume and decrease of the salt input with the Sea of Azov waters) factors leaded to the bay water freshening. Finally, the volume of the bay waters $\Delta B\left(\mathrm{~km}^{3}\right)$ was significantly larger - from 1.17 to $1.67 \mathrm{~km}^{3}$ - in comparison with the bay water volumes before the start of the NCC functioning $\left(0.63-0.81 \mathrm{~km}^{3}\right)$ (Table 1).

After the NCC overlapping in 2014, such fresh water input item as the NCC drainage and discharge waters was decreased. This, as is indicated by MHI expeditionary studies for 2014-2016, resulted in a salinity increase in the eastern part of the bay. Dynamics of the bay water salinity is given in detail in $[10,11]$.

The bay volume after the NCC overlapping $\left(0.56-0.63 \mathrm{~km}^{3}\right.$ ) (Table 1) was calculated taking into account the river runoff and precipitation changes, as well as in consideration of water exchange intensity with the Sea of Azov depending on prevailing wind and calculated bay level variation. The obtained data confirm the onset of transition period in the bay state and gradual approach to the regime of conditionally-natural state which was characteristic of 1939-1971.

The precipitation falling on the Sivash Bay surface has a pronounced seasonal course with the maximum in warm period (May - July) and the minimum in the cold one. Such precipitation distribution (continental type) is typical for the western Crimea and the northern Black Sea [17].

From the NCC overlapping (from 2014 to 2016) the mean precipitation was $361 \mathrm{~mm} /$ year. Taking into account the fact that the water surface area is $2540 \mathrm{~km}^{2}$, the volume of fresh water getting into the Sivash Bay as precipitation makes up $0.85 \mathrm{~km}^{3}$ per year.

When calculating water balance of the bay, the intensity of the bay water exchange with the Sea of Azov before the canal overlapping is very important input component of water balance. This is described in detail in $[8,14]$ taking into account fresh water volume dynamics varying over the year due to the existing irrigation systems (Fig. 1) [5].

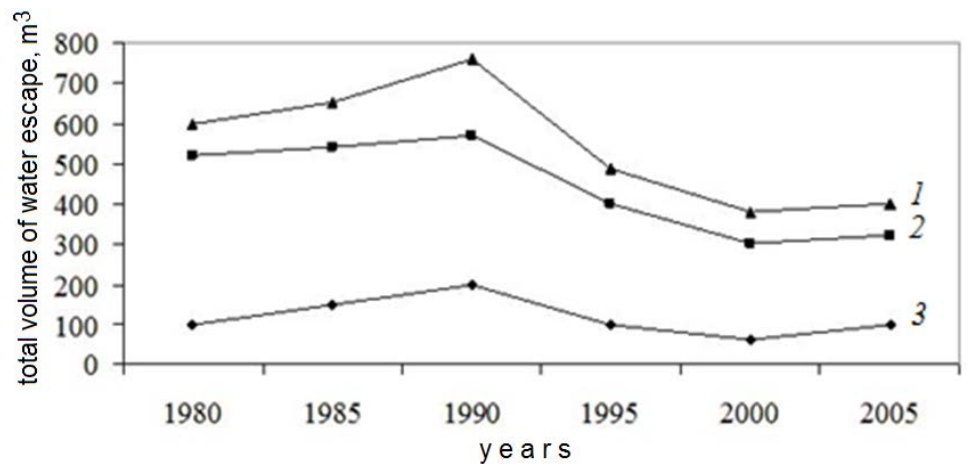

Fig. 1. The dynamics of fresh water volumes getting into the Sivash Bay [5]: 1 - from all sources; 2 from the NCC; 3 - from the Kahovskaya irrigation system 
Variation of water exchange intensity through the Henichesk Strait is affected by climatic changes near the Sea of Azov and the Sivash Bay which manifest themselves in the wind activity at the coast of the Azov and Black seas and level variations in the bay and the sea $[13,16,17]$.

It should be noted that during conditionally natural regime of the Sivash Bay the minimum current velocity and water discharge were observed in the Tonkiy Strait $[1,2]$. In this period annual average elevations of sea level over the one of the bay made up $14 \mathrm{~cm}$, in some years they increased to $19-20 \mathrm{~cm}$.

According to [14], in 1966-1975 annual average level elevations of the Sea of Azov over the level of the Eastern Sivash Bay decreased down to $6 \mathrm{~cm}$ due to construction of Biyuk-Naymansk Dam, separating the Western Sivash from the Eastern one, and the beginning of the NCC operation. During 1976-2006, when the discharge of sewage and drainage waters into the Sivash Bay reached the maximum values, level drop between MH Henichesk and MHP Chongar Bridge decreased to $3 \mathrm{~cm}$ and the maximum freshening of the Sivash Bay was observed.

Due to natural and climatic causes (decrease of precipitation falling on the bay surface) as well as decrease in the water supply through the canal (Fig. 1), annual average elevations of the Sea of Azov level over the one of the bay increased up to 10-13 cm from 2009 and the Sivash Bay salinization has gradually begun.

Annual average values of the bay water salinity near MHP Chongar Bridge were increased from the minimum value of 15.61 \%o in 2009 to 21.42 \%o in 2012 [14]. From 2014, after the NCC overlapping and, correspondingly, the change in environmental management system (rice production termination) and decrease of sewage water discharge into the Sivash Bay salinity was further increased [11]. According to our data from July 5, 2017 water salinity in the area affected by the Chongar Strait $\left(45^{\circ} 53^{\prime} 33.0^{\prime \prime} \mathrm{N} 34^{\circ} 28^{\prime} 39.2^{\prime \prime} \mathrm{E}\right)$ was $53 \%$.

In order to assess the intensity of water exchange through the Tonkiy Strait after the NCC overlapping the analysis of wind activity in the Azov - Black seas over 2014-2016 was performed [12]. Wind regime determines the water circulation, wind waves, surge phenomena, the Sea of Azov level fluctuations. During the work regular meteorological data of MH Henichesk from 2014 to 2016 were analyzed, wind frequency roses (percent) for each season on the basis of daily average data were plotted (Fig. 2). It is shown that in all seasons prevails the eastern wind - from $20 \%$ in spring to $31 \%$ in autumn. The western wind, providing the surge of the Sivash Bay water into the Sea of Azov, has significantly smaller frequency - from $8 \%$ in autumn to $15 \%$ in spring. The highest average wind velocity is observed in autumn and in winter - $4.9 \mathrm{~m} / \mathrm{s}$ and $4.5 \mathrm{~m} / \mathrm{s}$, respectively. In spring wind velocity decreases down to $4 \mathrm{~m} / \mathrm{s}$, in summer - to $3 \mathrm{~m} / \mathrm{s}$. The analysis revealed that at MH Henichesk in 2014 weak winds (to $4 \mathrm{~m} / \mathrm{s}$ ) prevail and they make up $78 \%$, the frequency of strong winds $(10-24 \mathrm{~m} / \mathrm{s})$ is $10.5 \%$. It should be pointed out that during the entire year the northeastern and eastern winds prevail (70 \%). It is concluded that wind conditions (the prevalence of eastern winds) contribute to the water level increase in the Sivash Bay due to the surge of the Sea of Azov waters through the Tonkiy Strait.

Evaporation - an output item of the Sivash Bay water balance - is one of the hard-to-determine parameters, maybe that is why in some works only input items 
of the balance are given. According to our data, after the NCC overlapping the evaporation from the Sivash Bay surface made up about $1.86 \mathrm{~km}^{3}$ per year.

The main feature of the Sivash Bay hydrodynamic regime (especially of its most shallow parts) are surge phenomena directly related to the wind effect on the shallow water. The Sivash Bay has its own system of currents. Drift currents occur due to wind friction against the water and are changeable depending on its direction. Discharge currents occur because of the difference in levels of the Sivash Bay separate parts due to surge phenomena, river runoffs and temporary streams.
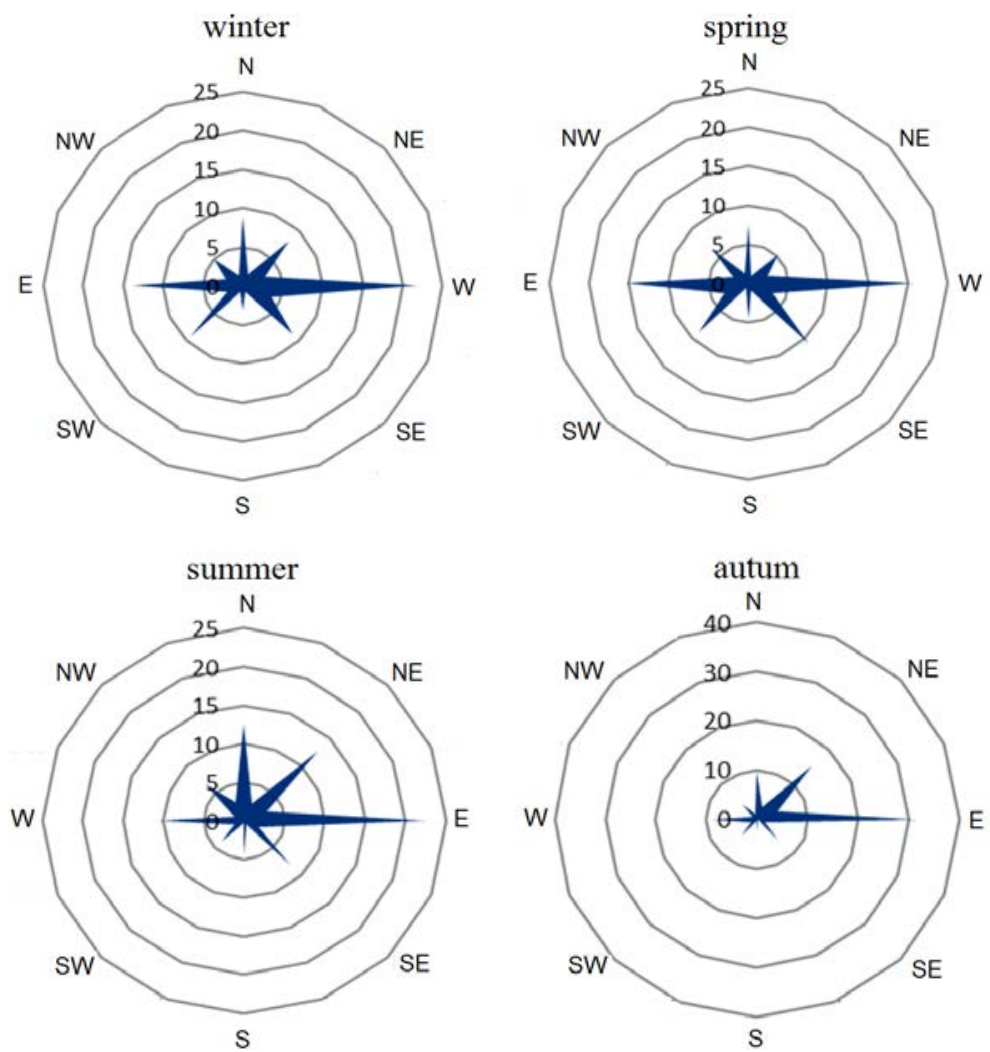

Fig. 2. Seasonal frequency roses (\%) of the wind at MH Henichesk from 2014 to 2016

The bay water level decrease in comparison with the one of the Sea of Azov surface is promoted by shallowness of the Sivash Bay water area, features of its hydrodynamic regime and evaporation from the water surface. Seasonal variability of the Eastern Sivash level [17] is characterized by high values in April almost all over the water area at significant decrease in summer due to evaporation and increase from August to October due to precipitation. General trend of water level decrease in spring-summer is also related to prolonged steady impact of wind of western rhumbs in the Eastern Sivash water area.

To study the features of the Eastern Sivash and the Sea of Azov water exchange through the Tonkiy Strait, a numerical non-stationary hydrothermodynamical model (a detailed description of which is given in [19]) was applied. 
During the calculations the Eastern Sivash water area was covered by horizontal computational grid of $76 \times 99$ nodes with $1000 \mathrm{~m}$ step. The values of wind direction and velocity (with $3 \mathrm{~h}$ discreteness) were set on the basis of data of observations carried out at MH Henichesk [12].

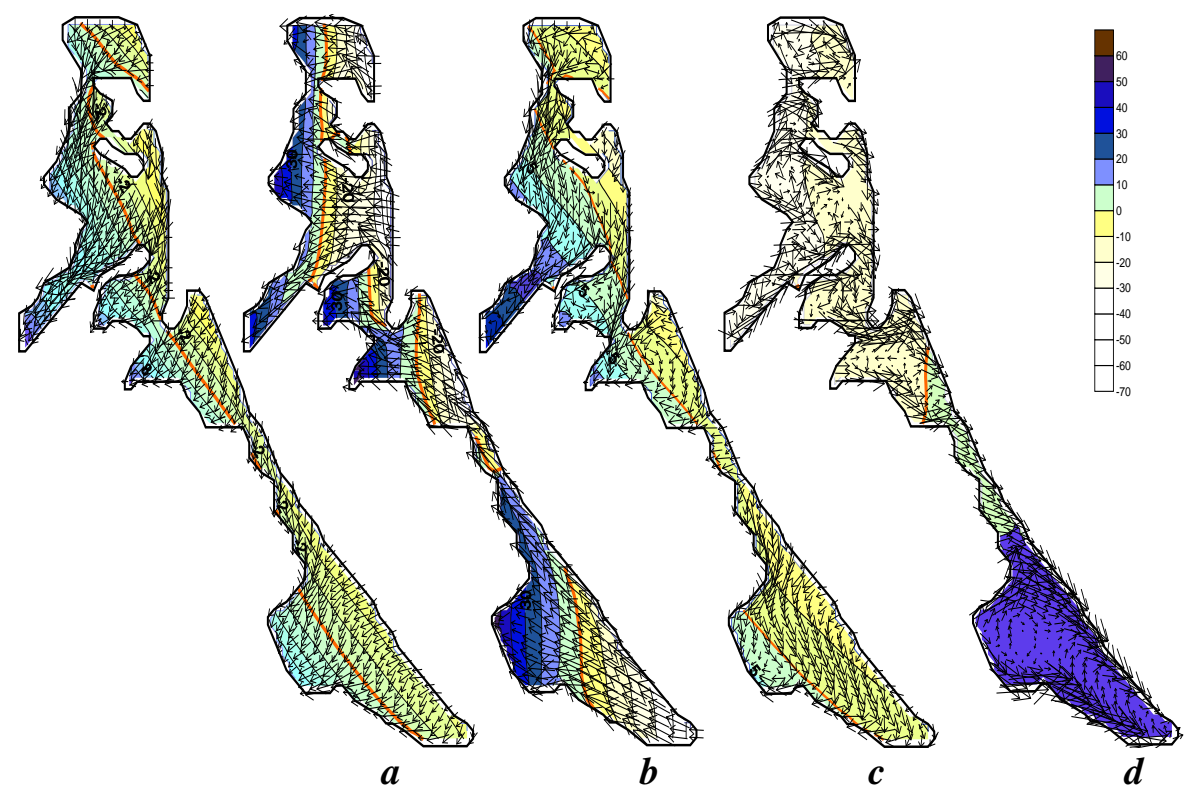

Fig. 3. Patterns of surface currents and level fluctuations $(\mathrm{cm})$ in the Eastern Sivash Bay at the winds of eastern directions: $a$ - at northeastern wind of $8 \mathrm{~m} / \mathrm{s}$ (May 31, 2014); $b$ - at an east-north-eastern wind of $10 \mathrm{~m} / \mathrm{s}$ (June 3, 2014); $c$ - at an eastern wind of $8 \mathrm{~m} / \mathrm{s}$ (July 18, 2014); $d$ - with a western wind of $4 \mathrm{~m} / \mathrm{s}$ velocity (June 9, 2014)

The current variations and level fluctuations in the Eastern Sivash were calculated at meteorological situation corresponding to May - July 2014. In Fig. 3 the patterns of surface currents and level fluctuations $(\mathrm{cm})$ in the Sivash Bay at the winds of eastern (May 31, June 3, July 18, 2014) and western (June 9, 2014) rhumbs are shown. It can be seen that at predominating winds of eastern directions an intensification of the Sea of Azov water inflow to the Sivash Bay is possible. Definitely, this can promote its salinization.

\section{Conclusions}

1. On the basis of the components of the Sivash Bay water balance during conditionally natural bay state (1939-1971) and the NCC active functioning at different modes of the Crimean and Kahovskaya irrigation systems (1972-2013) it is shown that the bay freshening and increase of its volume are due to impact of both anthropogenic (the NCC functioning) and natural-climatic factors.

2. The intensity of the bay water exchange with the Sea of Azov after the NCC overlapping are estimated on the basis of analysis of wind seasonal dynamics in the Sivash Bay water area over 2014-2016 and calculated level variation in the Sivash Bay and the Sea of Azov. It is shown that in the given period the winds of eastern rhumbs predominated in the water area. They increase the inflow of the Sea of Azov waters to the bay which leads to its salinization. 
3. After the NCC overlapping in 2014 the existing anthropogenic (environmental management system change) and natural-climatic factors contribute to gradual salinization of the bay, decrease of its volume and transition to conditionally-natural state.

\section{REFERENCES}

1. Kostyushin, V.A. and Gorodiskaya, G.A. eds., 2000. The Current Status of Sivash (as a Wetlands): Collection of Scientific Papers. Kiev: Wetlands International-AEME, 104 p. (in Russian).

2. Kostyushina, V.A. and Fesenko, G.V. eds., 2007. Sivash Region: a brief socio-economic overview. Kiev: Wetlands International Black Sea Progr., 178 p. (in Russian).

3. Ponizovsky, A.M., 1965. Solyanye Resursy Kryma [The Salt Resources of the Crimea]. Simferopol: Krym, 163 p. (in Russian).

4. Ponizovsky, A.M. and Chernyshev, M.P., 1963. O Gidrologicheskoy i Gidrokhimicheskoy Kharakteristike Azovskogo Morya i Sivasha v Svyazi s Osvoeniem Vodoema [On Hydrologic and Hydrochemical Characteristic of the Sea of Azov and the Sivash Bay due to the Development of the Water Area]. In: Voprosy Kompleksnoy Pererabotki Rassolov Morskogo Tipa i Poluchenie Rapnykh Stroymaterialov [Issues of Complex Processing of Salt Brines and Production of Brine Building Materials]. Simferopol: Krymizdat, pp. 77-83 (in Russian).

5. Marushevsky, G.B., Kostyushin, V.A. and Siohin, V.D., 2005. The Sivash: Nature and People. Kiev: The Black Sea program Wetlands International, 80 p. (in Russian).

6. Dyakov, N.N., Fomin, V.V. and Gorbach, S.B., 2012. Sovremennyy Metod Rascheta Kolichestva Atmosfernykh Osadkov, Vypadayuschikh na Poverkhnost' Azovskogo Morya [The Modern Method for Calculating the Precipitation Falling on the Surface of the Sea of Azov]. In All-Ukrainian Scientific-Practical Conference "Ecology of Cities and Recreation Zones": proceedings of the conference. Odessa: INVATS, pp. 60-61 (in Russian).

7. Dyakov, N.N., Belogudov, A.A. and Timoshenko, T.Yu., 2013. Otsenka Sostavlyayuschikh Vodnogo Balansa Zaliva Sivash [Assessment of Water Balance Components of the Sivash Bay]. In: MHI, 2013. Ekologicheskaya Bezopasnost' Pribrezhnoj i Shel'fovoj Zon i Kompleksnoe Ispol'zovanie Resursov Shel'fa [Ecological Safety of Coastal and Shelf Zones and Comprehensive Use of Shelf Resources]. Sevastopol: MHI. Iss. 27, pp. 439-445 (In Russian).

8. Dyakov, N.N., Fomin, V.V. and Gorbach, S.B., 2011. Sovremennyy Vodoobmen Azovskogo Morya s Zalivom Sivash cherez Proliv Tonkiy [Modern Water Exchange of the Sea of Azov with the Sivash Bay across the Tonkiy Strait]. In: All-Ukrainian Scientific-Practical Conference "Ecology of Cities and Recreation Zones": proceedings of the conference. Odessa: INVATS, pp. 80-83 (in Russian).

9. Sovga E.E. and Shchurova, E.S., 2013. Resursnyy Potentsial Ozera Sivash i Sovremennoe Ekologicheskoe Sostoyanie ego Akvatorii [Resource Potential of the Sivash Bay and Current Ecological State of its Water Area]. In: MHI, 2013. Ekologicheskaya Bezopasnost' Pribrezhnoj i Shel'fovoj Zon i Kompleksnoe Ispol'zovanie Resursov Shel'fa [Ecological Safety of Coastal and Shelf Zones and Comprehensive Use of Shelf Resources]. Sevastopol: MHI. Iss. 27, pp. 276-284 (in Russian).

10. Pozachenyuk, E.A., Sovga, E.E., Khmara, T.V., Kharitonova, L.V. and Shchurova, E.S., 2016. O Metodakh Otsenki Sovremennogo Sostoyaniya Akvatorii Zaliva Sivash v Usloviyakh Perekrytiya Severo-Krymskogo Kanala v 2014 Godu [Methods of Assessment of the Sivash Lagoon State under the North-Crimean Canal Overlap in 2014]. In: MHI, 2016. Ekologicheskaya Bezopasnost' Pribrezhnoj i Shel'fovoj Zon i Kompleksnoe Ispol'zovanie Resursov Shel'fa [Ecological Safety of Coastal and Shelf Zones and Comprehensive Use of Shelf Resources]. Sevastopol: MHI. Iss. 4, pp. 41-49 (in Russian).

11. Shchurova, E.S., Sovga, E.E., Khmara, T.V., Lomakin, P.D., 2016. Izmenenija Resursnogo Potenciala Zaliva Sivash (Azovskoe More) posle Perekrytija Severo-Krymskogo Kanala v 2014 Godu [Changes in the Resource Potential of the Sivash Bay (the Sea of Azov) after the North-Crimean Canal Overlap in 2014]. In: SFU, 2016. Ekologija. Ekonomika. Informatika. Azovskoe More, Kerchenskij Proliv i Predprolivnye Zony v Chernom More: Problemy 
Upravlenija Pribrezhnymi Territorijami dlja Obespechenija Jekologicheskoj Bezopasnosti i Racional'nogo Prirodopol'zovanija: sbornik materialov III Vserossijskoj konferencii [Ecology. Economy. Informatics. The Sea of Azov, the Kerch Strait and Near-Strait Zones in The Black Sea: The Problems of Management of Coastal Territories to Ensure Ecological Safety and Sustainable Nature Exploitation: proceedings of the 3d all-Russian conference]. Rostov-on-Don: SFU Publ., pp. 296-307 (in Russian).

12. Weather schedule [online]. Available at: https://rp5.ru/ [Accessed 06 September 2017].

13. Adler, R.F., Huffman, G.J., Chang, A., Ferraro, R., Xie, P-P., Janowiak, J., Rudolf. B., Schnider, U. and Curtis, S. [et al], 2003. The Version-2 Global Precipitation Climatology Project (GPCP) Monthly Precipitation Analysis (1979-Present). J. Hydrometeorol., [e-journal] 4(6), pp. 1147-1167. Available at: https://journals.ametsoc.org/doi/abs/10.1175/15257541\%282003\%29004\%3C1147\%3ATVGPCP\%3E2.0.CO\%3B2 [Accessed 16 April 2018].

14. Dyakov, N.N. and Belogudov, A.A., 2015. Vodoobmen Zaliva Sivash s Azovskim Morem cherez Proliv Genicheskij (Tonkiy) [Water Exchange of the Gulf Sivash with the Sea of Azov through the Strait Genichesk (Tonkiy)]. In: SOI, 2015. SOI Proceedings. Moscow: SOI. Iss. 216, pp. 240-253 (in Russian).

15. Matveev, L.T., 1984. Kurs Obshhej Meteorologii: Fizika Atmosfery [The Course of General Meteorology: Physics of Atmosphere]. Leningrad: Gidrometeoizdat, pp. 341-346 (in Russian).

16. Giovanni. The Bridge between Data and Science. v 4.23 Release Notes Browser Compatibility Known Issues [online] Available at: https://giovanni.sci.gsfc.nasa.gov [Accessed: 06 September 2017].

17. Ilyin, Yu.P., Repetin, L.N. and Belokopytov V.N., 2012. Gidrometeorologicheskie Usloviya Morey Ukrainy. T. 2: Chernoe More [Hydrometeorological Conditions of the Seas of Ukraine. V. 2: The Black Sea]. Sevastopol: EKOSI-Gidrofizika, 421 p. (in Russian).

18. Altman, E.N., 1973. Vodooobmen cherez Kerchenskij Proliv v Uslovijah Zaregulirovannogo Stoka Rek Azovskogo Bassejna [Water Exchange through the Kerch Strait under Regulated River Discharge of the Azov Basin]. Okeanologiya, XIII (3), pp. 416-423 (in Russian).

19. Ivanov, V.A. and Tuchkovenko, Yu.S., 2006. Prikladnoe Matematicheskoe Modelirovanie Kachestva Vod Shel'fovykh Morskikh Ekosistem [Applied Mathematical Modeling of Water Quality of the Shelf Marine Ecosystems]. Sevastopol: EKOSI-Gidrofizika, 368 p. (in Russian).

\section{About the authors:}

Elena E. Sovga - Leading Research Associate, Shelf Hydrophysics Department, FSBSI MHI (Sevastopol, Russian Federation), Dr.Sci. (Geogr.), ResearcherID: A-9774-2018, esovga@mhi-ras.ru.

Tat'yana V. Khmara - Junior Research Associate, Shelf Hydrophysics Department, FSBSI MHI (Sevastopol, Russian Federation), ResearcherID: C-2358-2016, xmara@mhi-ras.ru.

Ekaterina S. Eryemina - Junior Research Associate, Shelf Hydrophysics Department, FSBSI MHI (Sevastopol, Russian Federation), ResearcherID: E-8676-2018.

\section{Contribution of the co-authors:}

Elena E. Sovga - scientific supervision of the research, setting out the objectives and tasks of the research; the processing and description of the results of the study, participation in the discussion of the article materials, formulation of the conclusions, preparation of annotation text, critical analysis and revision of the text, preparation of the article text.

Ekaterina S. Eryemina - analysis of the materials on the research theme, literature review in the research problem, construction of graphs and diagrams, selection and analysis of the literature, participation in the discussion of the article materials.

Tat'yana V. Khmara - correction of mathematical model and carrying out the calculations, participation in the discussion of the article materials, preparation of the initial version of the text, preparation of the article text, revision of the text.

All authors have read and approved the final manuscript.

The authors declare that they have no conflict of interest. 